\title{
シルミン $(\mathrm{AC} 3 \mathrm{~A})$ 乾式切削における超硬合金工具摩耗について*
}

\author{
財満鎮 雄** 高辻雄三*** 山田 茂***
}

J. Japan Inst. Metals. Vol.46. No.6(1982), pp.657-664

Some Consideration on Carbide Tool Wear in Dry Cutting of Silumin

\section{Shigeo Zaima**, Yuzo Takatsuji*** and Shigeru Yamada***}

Carbice tool wear of $\mathrm{P} 10$ tool and $\mathrm{K} 10$ tool was studied from the view point of rake surface wear by means of EPMA in dry cutting (AC3A). The pulled up pits are recognized on the tool edge and rake surface of both tools, and it is observed that carbide particls fell off due to diffusion of $\mathrm{Co}$, and the wear in the crater part progresses by scratch of hard fine silicon particles, etc. in work material. The concentration of Co remaining at the tool surface of $\mathrm{K} 10$ tool is higher than that of P10 tool. Therefore, it is obviously shown that the falling of binding strength of K10 tool is small compared with P10 tool and consequently progresuion of the tool wear of K10 tool is slow.

(Received February 20, 1982)

\section{I. 緒言}

普通の鉄鋼系材料の切削にるみら礼ないよらな激しい工 具摩耗を伴う $\mathrm{A} 1-\mathrm{Si}$ 系釷造合金の切削では切削抵抗の軽 減, 潤滑などKよって, 工具摩耗の減少の観点から，切削 油剂を使用した湿式切削が試みられることも少なくない。 しかしながら，切削油剂を使用して切削仕上げした場合， 製品として塗装中，塗装後あるい使用中に切削油剤がに し゚み出したりすることがあるため，止むを得ず乾式切削を することが多い。この上らな場合。工具摩耗が激しいこ 之，金属光沢を有する良好な切削面が得られにくいことな どのため，一般に Al-Si 系鋳造合金は難削材に属するとい われている。本報では，代表的な $\mathrm{A} 1-\mathrm{Si}$ 系鋳造合金として AC3A（いわゆるシルミン)について，超硬合金工具を使用 した峺式切削に括ける工具摩耗をEPMAによって検討し た。さきに，この種合金に高速度鋼工具を使用した場合， 乾式切削では三角形逃げ面摩耗を呈し, 湿式切削では切込 みに相当する部分に境界摩耗が発生することを示し(1)(2), 引続き超硬合金工具を使用した湿式切削でも高速度鋼工具
の場合汪ど激しくはないが，同様な境界摩耗が発生するこ と，超硬合金工具材種のうち $\mathrm{P}$ 種より K 種が耐摩耗性が良 好なこと，括よびこの場合の工具摩耗の発生機構仿ていて のEPMA による見解などについて報告した ${ }^{(3)}$.よって，超 硬合金工具に上る乾式切削の場合も高速度鋼工具の乾式切 削の場合之同様な摩耗形態を示すかどうか，超硬合金工具 材種 ( $\mathrm{P}$ 種，K種)による耐摩耗性の差異などを明らかにす ることなと゚を目的とした。

\section{II. 実 験 要 項}

実験に供した試料は Table 1 亿示卞化学成分，機械的 性質を有する前報 ${ }^{(3)}$ 季でのものと同一の AC3A 枋である。 刃先諸元 $0-\pi / 18-\pi / 30-\pi / 30-\pi / 30-0-0$ を有する 2 種類の 超硬合金工具 (IIS 分類 P10 および K10) 使用し, 昌運力 ズヌープ旋盤 HB-500 型 (主軸回転数 40 3200 rpm (0.6 $\left.53.3 \mathrm{~s}^{-1}\right)$ )によって切削試験を実施した。

切削条件は削り速度 $v=9 \mathrm{~m} / \mathrm{s}$, 切込久 $t_{1}=1.0 \mathrm{~mm}$, 送 り $f=0.1 \mathrm{~mm} / \mathrm{rev}$ 一定とし, 連続乾式切削時間を $\mathrm{P} 10$, K10 そついてそれぞれ $t=420 \mathrm{~s}(7 \mathrm{~min}), t=720 \mathrm{~s}$ (12 min)

Table 1 Chemical compositions and mechanical properties of specimen used.

\begin{tabular}{c|c|c|c|c|c||c|c|c|c}
\hline \multirow{3}{*}{ Material } & \multicolumn{3}{|c||}{ Chemical compositions } & \multicolumn{5}{c}{ Mechanical properties } \\
\cline { 2 - 9 } & $\begin{array}{c}\mathrm{Si} \\
(\%)\end{array}$ & $\begin{array}{c}\mathrm{Fe} \\
(\%)\end{array}$ & $\begin{array}{c}\mathrm{Na} \\
(\%)\end{array}$ & $\begin{array}{c}\mathrm{Sn} \\
(\%)\end{array}$ & $\begin{array}{c}\mathrm{Al} \\
(\%)\end{array}$ & $\begin{array}{c}\text { Tensile strength } \\
(\mathrm{MPa})\end{array}$ & $\begin{array}{c}0.2 \% \text { Yield strength } \\
(\mathrm{MPa})\end{array}$ & $\begin{array}{c}\text { Elongation } \\
(\%)\end{array}$ & $\begin{array}{c}\text { Vickers hardness } \\
\text { Hv }\end{array}$ \\
\hline AC3A & 12.8 & 0.2 & 0.02 & 0.41 & bal & 135 & 71 & 4.0 & 49.5 \\
\hline
\end{tabular}

** 静岡大学工学部機械工学科 (Department of Mechanical Science, Faculty of Engineering, Shizuoka University, Hamamatsu)

**** 富山大学工学部生産機械工学科 (Department of Production Engineering, Faculty of Engineering, Toyama University, Takaoka)

* 1980 年 10 月日本金属学会福岡大会に発表 
とし，その時の工具摩耗状態をすくい面摩耗について検討 した，この場合，逃げ面摩耗がすくい面摩耗に先行する が, 工具の摩耗機構恃切屑が擦過するすくい面側でその特 色がはっりするのですくい面摩耗を対象とした。この とき逃げ面摩耗は定常状態になって括り，逃げ面摩耗幅は $\mathrm{P} 10, \mathrm{~K} 10$ 工具でそれぞれ $160 \mu \mathrm{m}, 45 \mu \mathrm{m}$ となり，すくい 面のクレータ深さはそれぞれ $1.5 \mu \mathrm{m}, 1.0 \mu \mathrm{m}$ となって拉 りやや少ないが特色は十分諗められるょうであった。こ の際, アルミニウムの大きな工具付着物は $\mathrm{NaOH}$ で除去 して切刃を観察した。

\section{P10 工具についての観察}

Photo.1 左側は P10 工具に批りるすくい面摩耗の全体 像と払大観察, 元素面分析部分 (图中の番号が後揭写真中 の部位番号を示す)扣よび線分析方向 (A，(B)，(C)で示す)を 示した説明図である。写真にみるように切刃端より約 400 $\mu \mathrm{m}$ の領域幅で工具摩耗が進行し，その摩耗形態は後述 Photo. 2 付図に示す上うに典形的なクレータの発生李でに は至っていないが，炭化物粒子の直径が $1 \mu \mathrm{m}$ 前後である ことを考慮すれば，摩耗現象の把握には十分であると思わ れる. 工具表面に多数付着している黒い付着物は炭素が主 成分の上らで，後述のよらに $\mathrm{TiC}$ 粒子の Tiが被削材中の アルミニウム中に拡散する際に遊離した炭素の集合体とみ られここの種の付着物はK種工具では観察されなかった。

Photo.2 はすくい面摩耗部分のうち，切成端近傍約 300 $\mu \mathrm{m}$ の領域幅の中で工具先端より切込及に相当する部分に かけての (1)，(2)，(3) 部分，その中央付近の(2)上り内部には いった切刃端より $300 〜 600 \mu \mathrm{m}$ の部分 (4)おびさらに内 側の摩耗終端部とみ×られる約 $600 \mu \mathrm{m}$ 以上の部分(5)の拡大 写真である。季た，右下の付図は Photo.1 のB方向の工具 表面形状を表面要方さ計(TALYSURF 4 型, 触針先端半 径 $12.5 \mu \mathrm{m})$ によって測定した結果である。あらさ計から

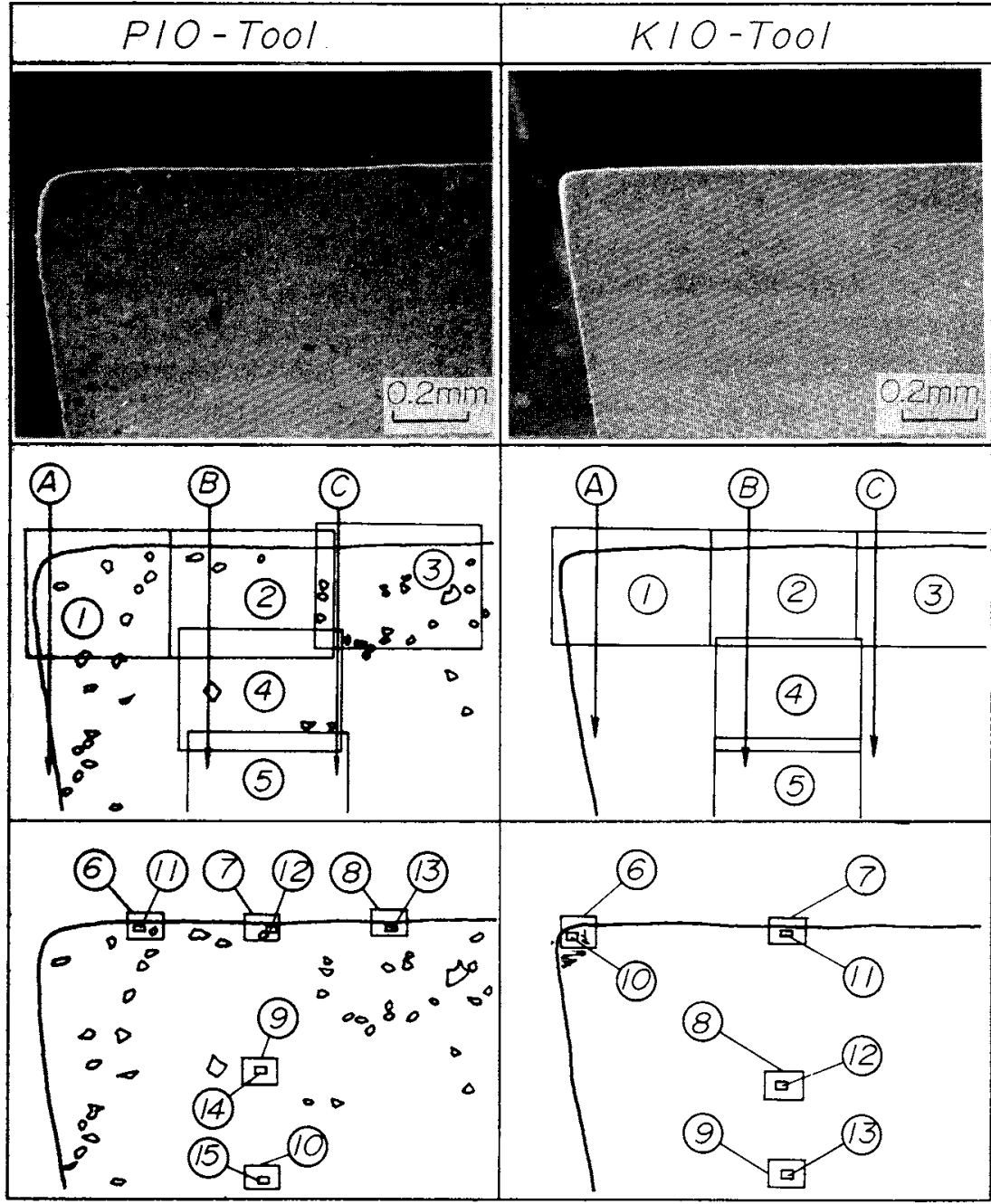

AC 3A, Dry Cutting

Photo.1 General views of tool wear of P10 and K10 tool. 


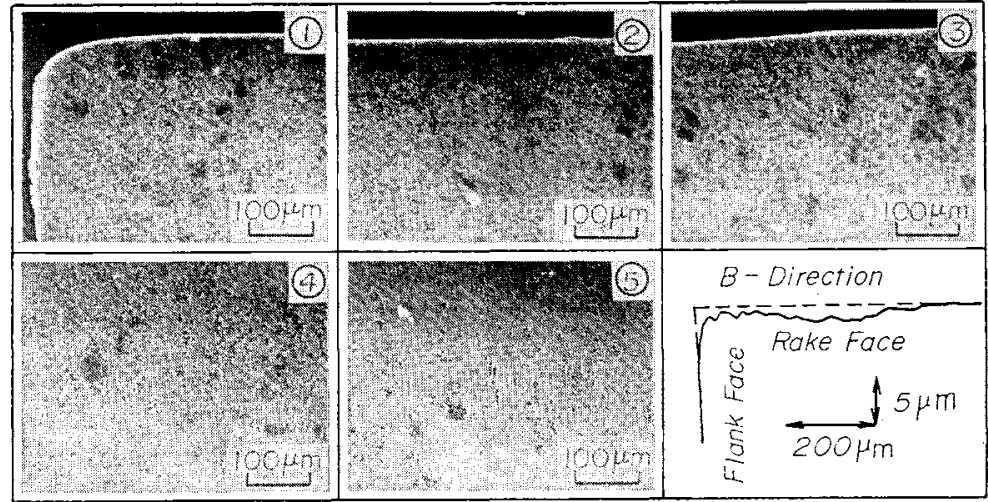

PlO-Tool, AC 3A, Dry Cutting
Photo.2 Secondary electron micrographs of various parts on worn face of P10 tool.
読み取れるクレータの最大深さは約 $1.5 \mu \mathrm{m}$ であるが，こ れは平均的な深さであり，部分的には写真(1)〜(3にみるよ らに触針のはいらない山みが多数あり，その深さは $3 \sim 5$ $\mu \mathrm{m}$ 程度である。このように(1)〜(3)部分では局部的に掘り 起された摩耗個所が点在し，(4)部分では摩耗部分はやや少 なく，(5)部分では表面的には长とんど摩耗していないよう にみられる。

ここで，(1)部分の一部を扗大した (6) 部分 Photo.3をみ れば，切冈端より約 $10 \mu \mathrm{m}$ の幅で摩耗によって角がだれ， その内側で全体として切局擦過によって炭化物粒子がばら ばらにえぐり取られた摩耗部分が多いのがかかる。とくに

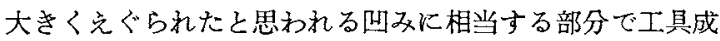
分の W， Ti，とくに Co が少なくなっているのがわかり， このよらな部分には必ずのの付着が珰められる。そして Si は切冈端に多く，逃げ面摩耗には Si が大さく作用して いることがらかが光。さらに，(6)部分の中央部を拡大し てみれば Photo.4の@のよらになり，炭化物粒子の脱落 状態がよくわかる．前記(2)部分の切刃㟨中央(7)部分を应大 すれば Photo.5 となる。(6)部分より摩耗部分はやや少な くなっているものの, 各所に炭化物粒子の脱落痕が認めb れ，また(3)部分の一部切刃端中央部の㹡大像(8)をみてる同 様な摩耗が認められる。ここで(7)，(8)部分のほぼ中央部 をさらに拡大寸れば Photo.4中のそれぞれ 12，18 となり， いずれる(1)の場合と同様な岸化物粒子の脱落状態を示して いる、これら (6)，(7)，(8)部分で共通していることはSi が 切刃端に付いていること，炭化物粒子の大きな脱落部分之 思われるところでW，Ti とくにCoが少ないこと，执よ びCが一様に付着していることである。この切刃端では Photo. 2 付図に示される形状で摩耗しているので，切削中 はこの部分に被削材が詰まり奶端から約 $100 \mu \mathrm{m}$ の幅で 切妇に沼ったプラト一部が形成され，この上を擦過した切 屑がプラトー部後力から直接工具に接触してクレータを形 成する，このためプラトー部では妡削熱のため工具材質中 のCo が堆積した被削材中へ桩散することが考劣られ，こ のことは Photo.3,Photo.5にみられる凹み部分で Co が著 しく減少している現象とよく一致している。この部分での

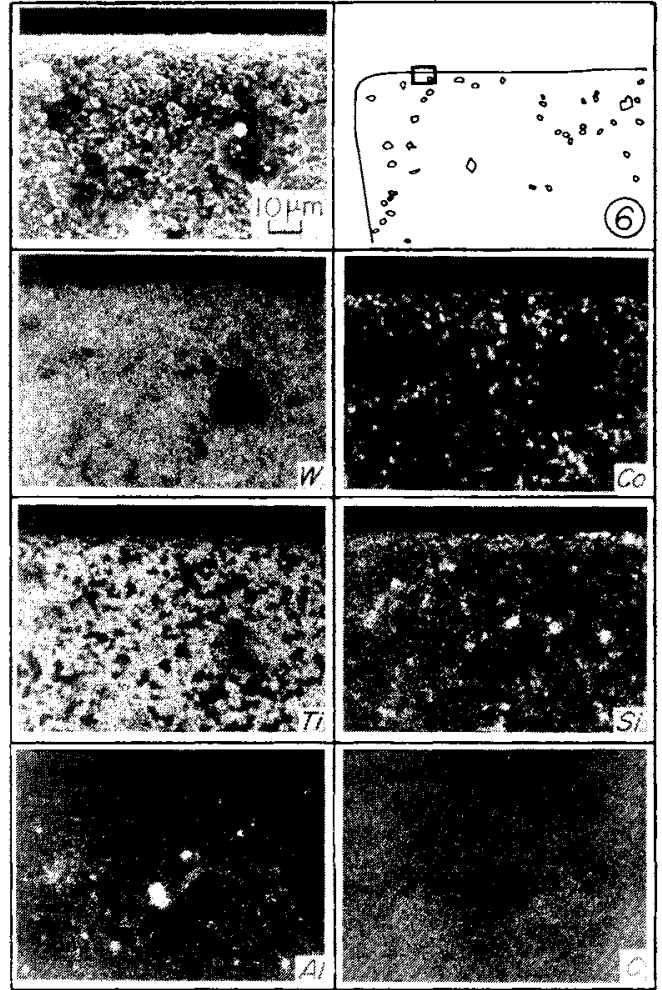

P/O-Tool, AC3A, Dry Cutting

Photo.3 Secondary electron and characteristic X-ray micrographs of front part on edge side of P10 tool.

摩耗は被削材中の硬質粒子による引蛋き作用ではなく，む しろプラトー部を形成している被削材中へのCＯＯ抎散が 生じ，この部分の結合強度が低下し，やがて粒子個々の 単位で脱落することで進行すると思われる。このことは Photo.4 の (11)，12，13で炭化物粒子にくずれた粒子がなく 1 個，1個が丸味を帯び，その閒にすきまが認められるこ とより明らかとみてよい。

比較的摩耗部分が少なくなっている(4)部分のほぼ中央部 (9)を拡大したるのが Photo.6である。摩耗面には切尿の 擦過痕があり，炭化物粒子が掘り起されたと思われる凹み 


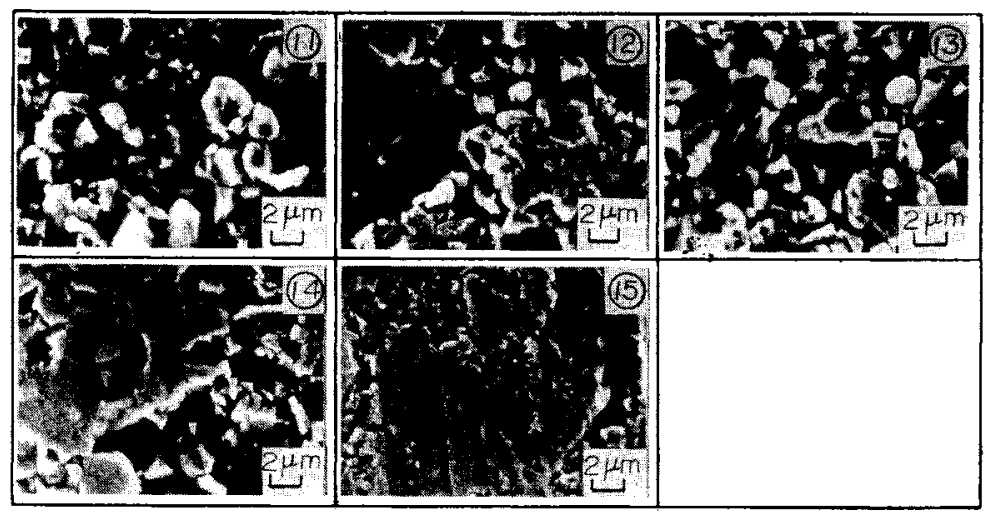

PIO-Tool, AC3A, Dry Cutting

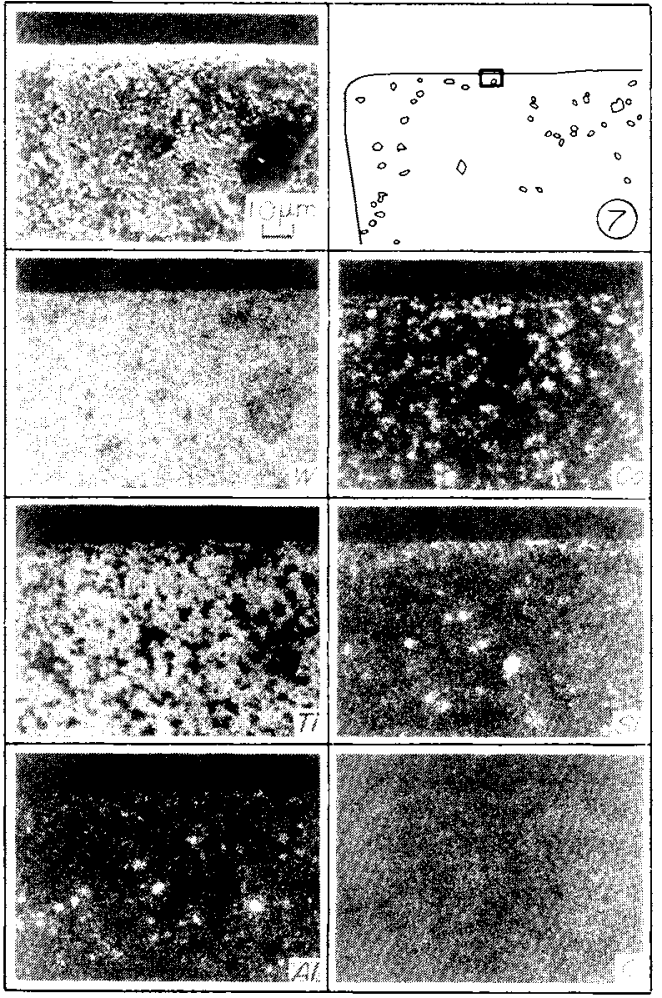

PIO-Tool, AC3A, Dry Cutting

Photo.5 Secondary electron and characteristic $X$-ray micrographs of center part on edge side of worn P10 tool.

部分に Si が多いこと，後述の未摩耗部分何に比べて Coが 少ないことなど特徵的である。(9)の中央部をさらに桩大す れば Photo.4 中の14となり，炭化物粒子の境目がしだいK はっきりし，やがて掘り起される様相がよくわかる，写真 左側の平坦部分は被削材中の硬質粒子に上って引租き取ら れた様相を示し，右側部分では切刃端の摩耗と同じ傾向を 示している。また，(5)部分の汪淩中央位部分を搪大すれば Photo.7となり，工具研削時の条痕が明らかに残って打 り, 研削に上る炭化物粒子の脱落痕と思われる部分以外で
Photo. 4 Various aspects of secondary electron micrograph on worn face of P10 tool.

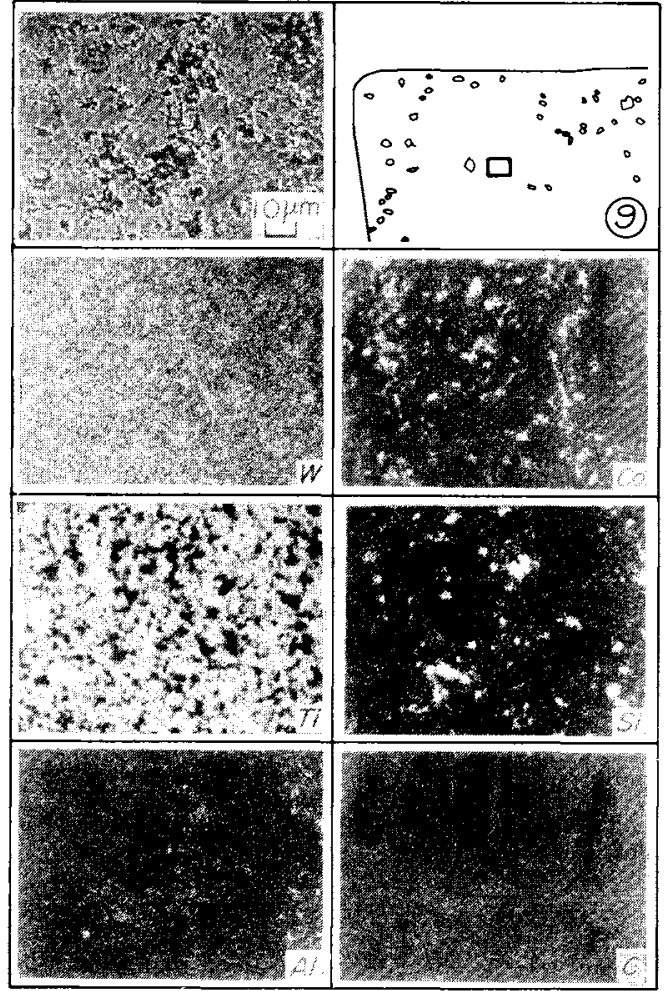

PIO-Tool, AC3A, Dry Cutting

Photo.6 Secondary electron and characteristic X-ray micrographs of terminal wear part of worn P10 tool.

は $\mathrm{Co}$ る比較的全面に分布している，その中央部何のさら に桩大したPhoto.4 (15)をみても，未摩耗部分の工具表面

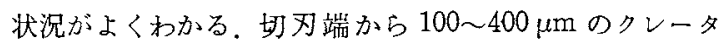
部分では主に引搯きによる摩耗が進行するが，この部分で 局部的に工具粒子が掘り起されたり，あるい性工具研削条 痕の凹みに切首が流れこむとCo の㹡散が生じ, 写真凹の 右側に2られる摩耗が生ずるものと思われる。

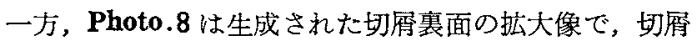
の流出方向は写真中右上りの対角線方向であるが，写真に みられる流れの間隔恃 Photo.6にみられる炭化物粒子の大 


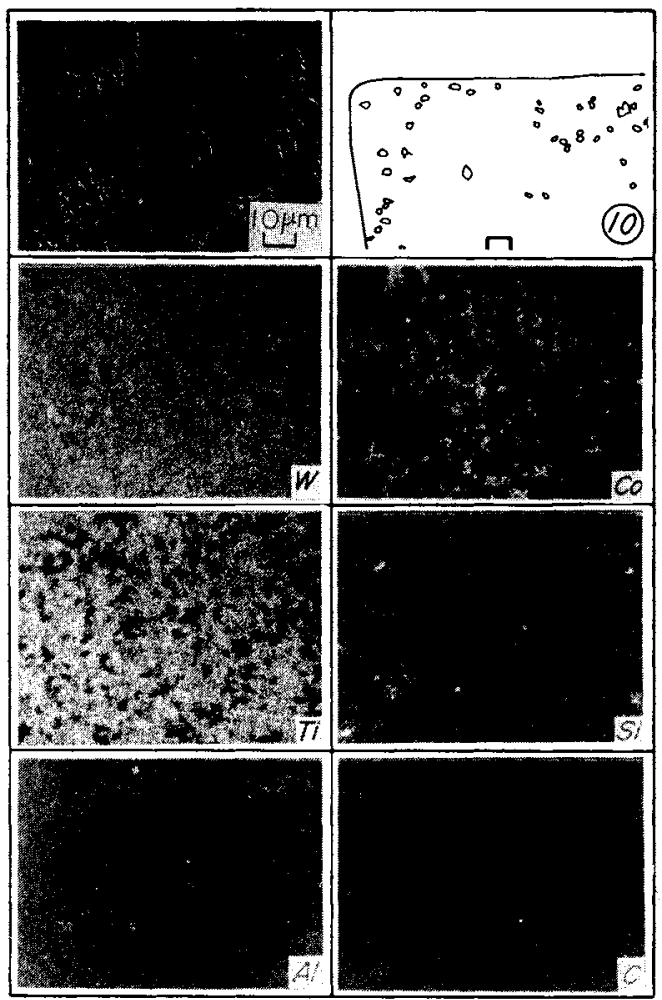

PIO-Tool, AC3A, Dry Cutting

Photo.7 Secondary electron and characteristic X-ray micrographs of overran part of crater of worn P10 tool.

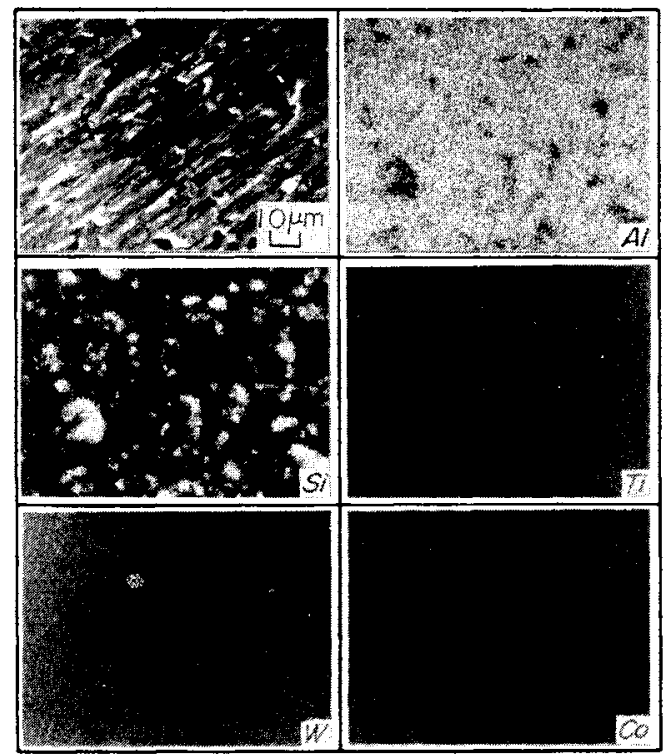

PIO-Tool, AC 3A, Dry Cutting

Photo. 8 Secondary electron and characteristic $X$-ray micrographs of cross section of chips in dry cutting with P10 tool.
きさに注注一致しており，硬い珪素粒子などが TiC，WC の粒子をわずかに引播き，その後を軟らかい活性なアルミ ニウムが擦過してメカノケミカル的に摩耗は進行するよ5 である。また，TiC 粒子の Ti と $\mathrm{A} 1$ は親和性が強いため， $\mathrm{TiC}$ 粒子中の $\mathrm{Ti}$ が活性なアルミニウムと結合して持ち去 られ，WCより TiCの方が硬いにも拘わらず摩耗が進行 すると思われる。このため $\mathrm{TiC}$ 粒子のCが遊離され， Photo.1などにみられるよ5に工具すくい面に付着したと みられる。この現象は前報(4)で AC8A-T6 材をTiC を主 成分とするサーメット工具で切削した場合の炭素の特性 X 線像に㧧いて，工具之付着物の境界部分に炭素粒子の塊が 観察されたことと一致すると思われる。な拉，切眉裏面か らは W，Ti，Coなどの工具元素の検出はできなかった。

工具付着物について調べた結果を Fig.1 上段に示す。 線分析方向は Photo.1 (B) 方向で, 電子線径は約 $1 \mu \mathrm{m}$ で ある。図よりCo は切刃端から約 $300 \mu \mathrm{m}$ までは少ないが， その後は除々に增大している。 Ti とW ではやや少ないが，专礼以啳は注ぼ一定值を示し，ともに 同じ㑯向を示している．Si 虭炀端に多く付着し $600 \mu \mathrm{m}$

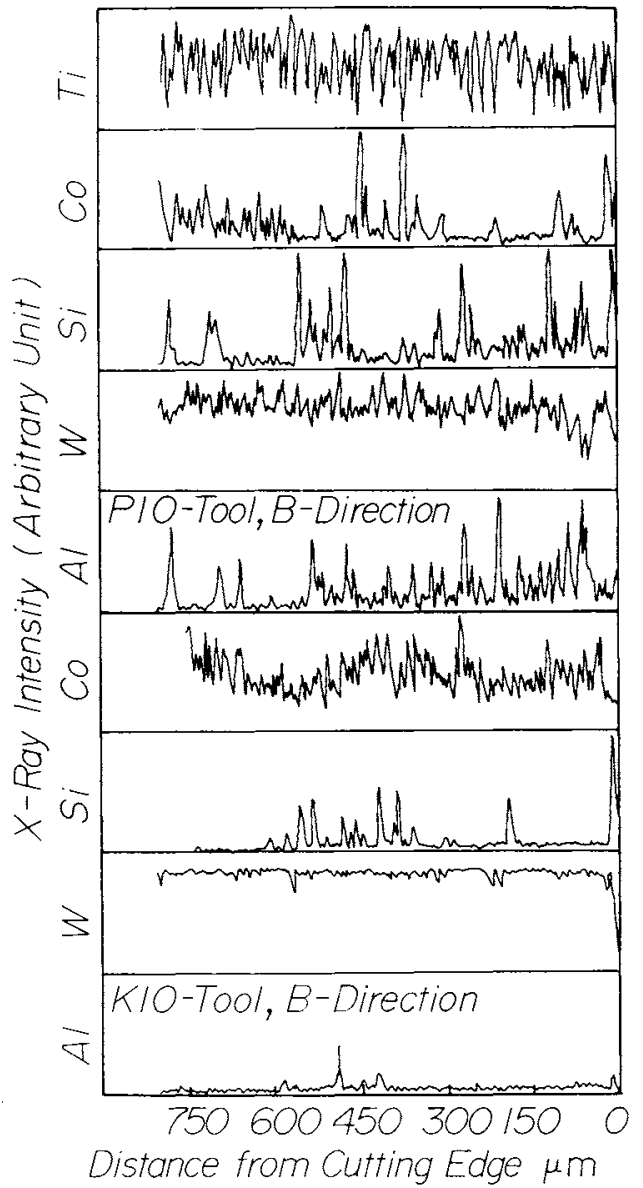

Fig.1 Characteristic X-ray intensity in depth direction of crater at $470 \mu \mathrm{m}$ from tool edge of P10 and K10 tool. 
をすぎる付近からやや少なめになっているが，その後もず っと付着している. Al は切对端に Si 汪ど多くは付いてい ないが，それ以外はSi の付着傾向と似ている。線分析は $800 \mu \mathrm{m}$ のところで止めてあるが，䄪 $850 \mu \mathrm{m}$ まで付着が 認められた。なお，(A，(C)の結果す（B）と似た㑯向を示し た。

\section{K10工具についての観察}

Photo. 1 右側は P10 工具の場合と同様に K10 工具に打 けるすくい面摩耗の全体像と拡大観察，元素面分析部分お
よび線分析方向を示す説明図である。写真にみるよらに P10 工具に比べて工具面もきれいで，摩耗も比較的少ない ことがわかる，P10工具の場合と同棣，切刃部 (1)，(2)，(3) およびやや内部の (4)，(5)部分の扗大写真を Photo.9 K示 す. 掘り起された凹み部分は P10 工具よりる少なく，炭 素の付着すないようである. 右下に示す表面形状より，ク レータ深さは約 $1 \mu \mathrm{m}$ と P10 工具に比べて小さく，クレー 幅る小さくなっている。しかし，摩耗量は少ないが表面 形状は P10 工具とほぼ同様であることから，摩耗形態る 類似しているとみてよい，このうら(1)部分中とくに摩耗が

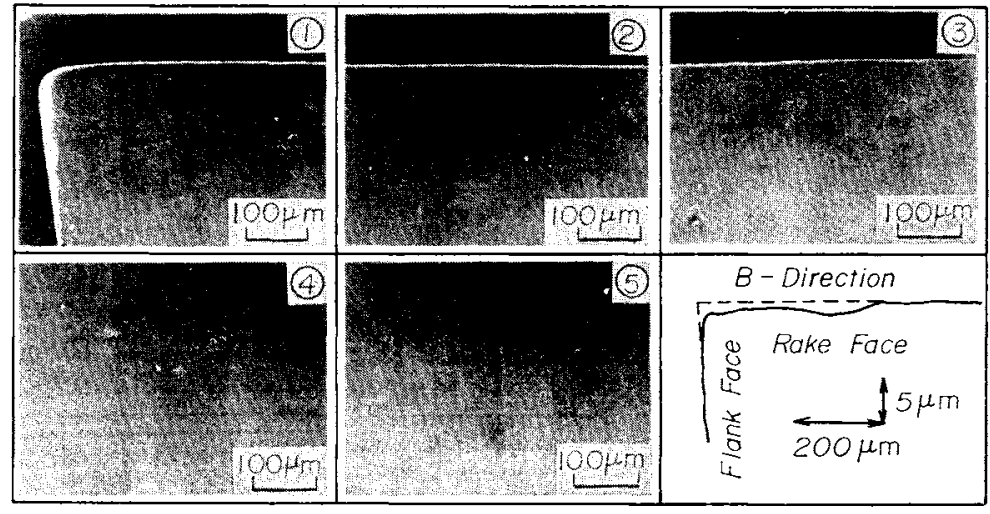

KIO-TOOl, AC3A, Dry Cutting

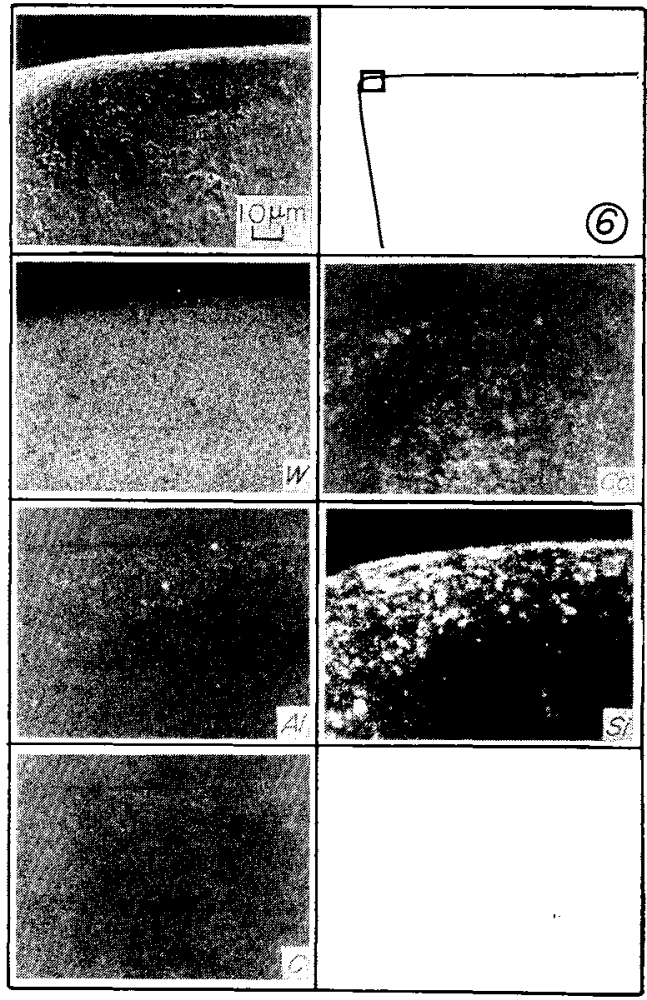

KIO-Tool, AC 3A, Dry Cutting

Photo.10 Secondary electron and characteristic $\mathrm{X}$-ray micrographs of worn tip of K10 tool.
激しい(6)部分の拡大像は Photo.10のようになり，P10工 具の場合より炭化物粒子が細かく脱落しているようで，之 くに切刃端より䄪 $20 \mu \mathrm{m}$ の領域幅で摩耗が著しく，摩耗 部分に $\mathrm{Si}, \mathrm{Al}$ が多く付着し，この部分ではCo が少なく なっている. (6)部分中摩耗の著しい個所をさらに拡大すれ ば Photo.1100よ5になり，炭化物粒子が全体として勫 かく，その脱落も $\mathrm{P} 10$ 工具の場合より極めて小さくなっ ている．この場合も切端に被削材によってプラトー部が 形成され，その付着物中に切削熱によってCo の拡散が生 し，摩耗が進行するものと思われる，前記(2部分の中央切

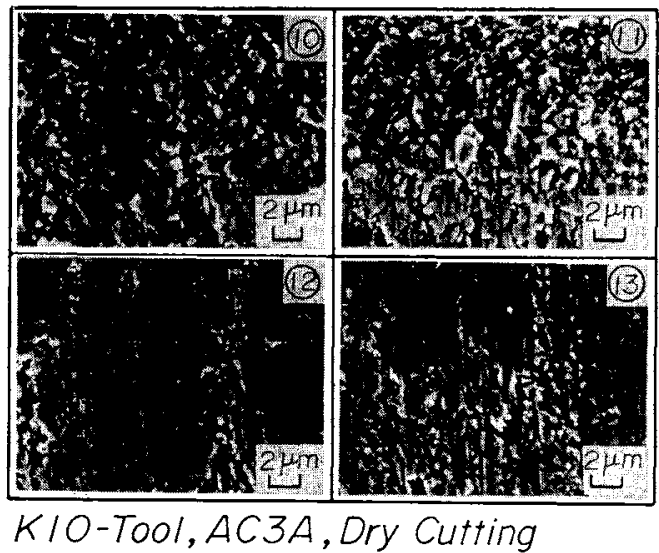

Photo.11 Various aspects of secondary electron micrograph on worn $\mathrm{K} 10$ tool. 
刃付近(7)を拡大した Photo.12をみても，切刃端より約 20 $\mu \mathrm{m}$ 程度の幅の領域て摩耗が甚だしく，その部分で $\mathrm{Si}$ ，A1 が多く、Coが少ない，それをさらに桩大した Photo.11中 の11をみても10の場合汪どではないが，炭化物粒子の脱落 状態がよくわかる。この写真上半分では(10)同様なCoの 拡散に上る摩耗が進行しているが，下半分では P10 の場 合の Photo.412の一部に及られた平坦部と同じ表面状態 で, 摩耗の初期段階と考光られる。

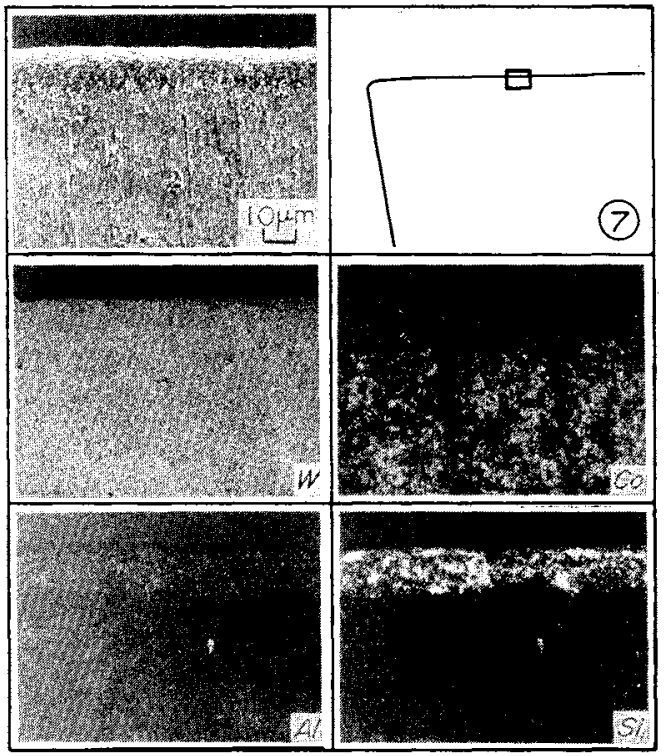

PIO-Tool, AC3A, Dry Cutting

Photo.12 Secondary electron and characteristic Xray micrographs of middle part on edge side of worn K10 tool.

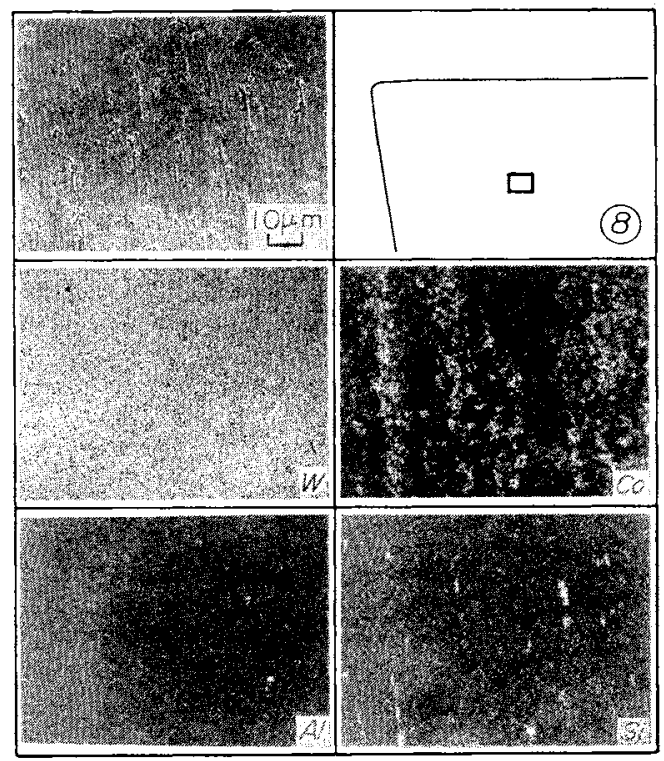

K1O-TOOl, AC3A, Dry Cutting

Photo.13 Secondary electron and characteristic Xray micrographs of overran part of crater of worn K10 tool.
工具摩耗が極めて少ないと思われる(4)部分の中央部(8)を 払大すれば Photo.13 となり，写真中，上下方向飞工具研

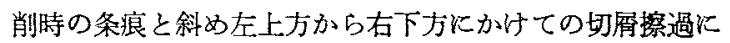
よる条痕とが交叉して認められ，工具研削傷と思われる部 分に $\mathrm{Si}$ が付着している。 さらに，その中央部之思われる部 分は Photo.11@のようになり，斜烧走った切屏擦過浪 と同写真中の汪とんと摩耗していない部分18の中にみられ る上下方向の研削条痕のちがいをはっきり示している。す なわち1場合の傷は比較的浅く、日では砥粒がかなり強 く研削した跡がみられる。回では切首が擦過して18亿みら れる条痕を徐々に削り取り，表面がいくぶんだれた状態で 滑らかになり，P10工具の場合と同様に主として硬い理素 粒子なとによる引蛋きと，軟らかいアルミニウムとの交互 の接触によるメカノケミカル的な摩耗が進行すると思われ る。この場合も擦過する切屏中への Co 拡散は考完られる が，引播きとる作用の方が大きいと思われる。

工具付着物の線分析結果は Fig.1 下段のようになる.Co は $300 \mu \mathrm{m}$ まで少しづつ減少した後增加して $400 \mu \mathrm{m}$ 前後 から再び減少し，600 $\mu \mathrm{m}$ を過ぎる付近からまた増加して いる、Wは切刃端で少し減少しているようであるが，その 後はほぼ一定の值を示している.Si は P10 工具の場合と

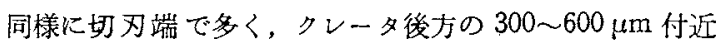

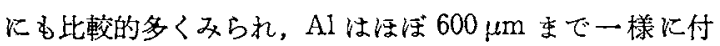
着して扣り，その後は少なくなっている。

\section{V. 検 討}

両工具とも，切刃端に拐いては Co の拡散によると思わ れる炭化物粒子の脱落, クレータ部に和いては硬い珪素粒 子などの引擂き作用による摩耗, そして部分的に掘り起さ れた四みで奵妇端と同様な形態て摩耗が進行すると思わ れる。このような摩耗は展伸材超々ジュラルミンの乾式切 削(5)で无観察されたが，湿式切削 ${ }^{(3)}$ では観察されなかっ た。これは湿式切削では切削温度が高くならないためで， 乾式切削では 700 900 K と切削温度も高く，切㞣も活性 であるなめCoの拆散が起ると考えられる。このため工具 表面の $\mathrm{Co}$ 濃度の変化を知ることは摩耗機構を考える上で 極めて重要である。いま，電子線径を約 $70 \mu \mathrm{m}$ と大きく して Fig.1 に示されたとほぼ同じ場所を趛してFig.2 を得たにビーム径が大きいため切刃端付近での分析精度は 良くない，P10工其ではCo 強度は汪湾クレータの最む深 いと思われる $300 \mu \mathrm{m}$ 寸ぎまで徐々に減少した後, クレー タが完全に終る $500 \mu \mathrm{m}$ までやや增加，クレータ後方の付 着物の多いところで減少，付着量のピークをすぎて徐々に 增加，その後付着物が全くなくなる $850 \mu \mathrm{m}$ をで增加してほ ぼ一定值をとるようになる。すなわち，Co 強度は摩耗部分 および付着物の付いた部分で減少していることがわかる。 Coが減少することは焼結強度の低下であり，表面的には 汪とえど摩耗していないクレータ後方であ強度が低下して 
いることがわかる，W，Ti b切冈端からクレータとかけて やや減少しているものの，Co㾁どではなく，クレータ後 方の付着物領域での減少もわずかである。

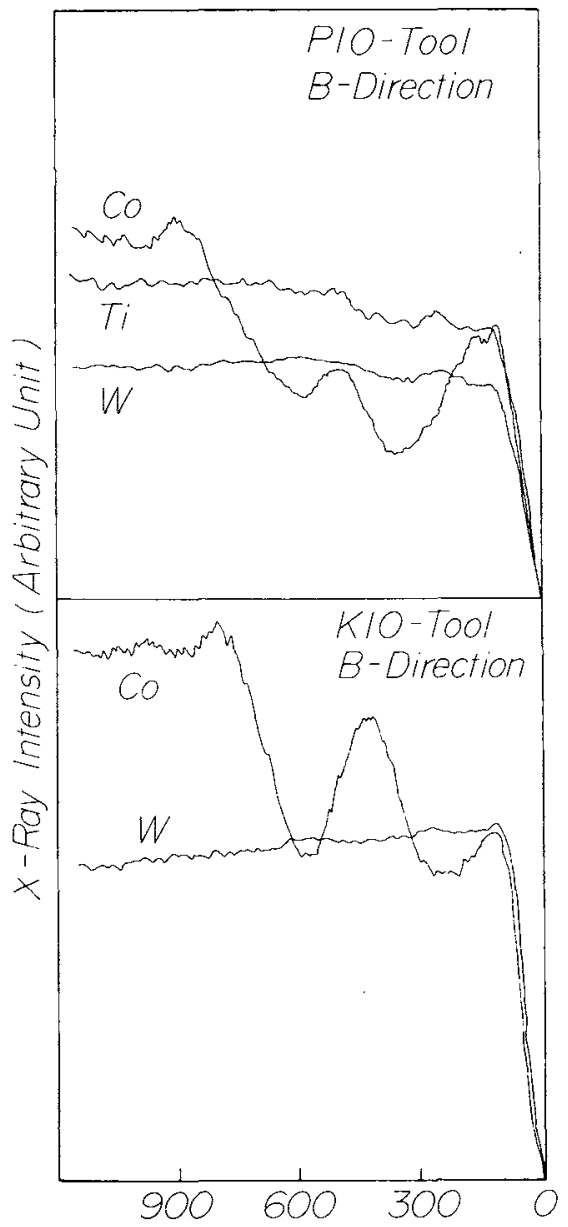

Distance from Cutting Edge $\mu \mathrm{m}$

Fig.2 Characteristic $\mathrm{X}$-ray intensity by using bold electron beams in the same case of Fig.1.
K10 工具でも同様な傾向がみられるが，P10 工具よりも 摩耗が少ないため，切入端からクレータ底までのCoの隇 少は少なく、クレータ後方の付着物も少ないため,この部 分に批ける Co 量もP10 工具よりは相対的に多くなってい る。前述の写真のように炭化物粒子の大きさは K10 工具 の方が細かく，残存 Co 量むP10工具よりる多くなるこ ともK10工具の耐摩耗性が良い原因の 1 つと考えられる。

\section{VI. 結言}

以上，超硬合金工具 $\mathrm{P} 10$ 特よび K10 によるンルミン (AC3A)の乾式切削に执いて,すくい面摩耗の見地から EPMA によって工具摩耗を検討した。 その結果, 両工具 とも切端敊よびすくい面上の掘り起された凹及では Co の拡散清よる炭化物粒子の脱落が観察され，クレータ部で は被削材中の硬い珪素微粒子などの引搔きによる摩耗の進 行が観察された。工具表面儿残存しているCo 量は P10工 具より K10 工具の方が多く，このため K10 工具で工具 摩耗の進行が遅いことがわかった。

本報の実施に当り，その費用の一部は(財)軽金属奖学会 の研究資金により，試料入手には前田軽金属工業秼式会社 木村勝一氏化負らところが大きかった。付記して深甚なる 謝意を表する。

\section{女献}

（1）財満鎮雄，鈴木康夫，奥島裕樹，山田 茂：軽金属， $31,5(1981), 341$.

（2）財満鎮雄，高辻雄三，奥島裕樹，山田茂：軽金属, $31,6(1981), 378$.

（3）財満鎮雄，高计雄三，奥島裕樹，山田 茂：軽金属， $31,10(1981), 660$.

（4）財满鎮雄，高过雄三，山田 茂：日本金属学会誌, $46(1982), 452$.

(5) 財満鎮雄, 高辻雄三, 山田 茂, 奥島裕樹 : 日本金 属学会誌, 46(1982), 108. 